\title{
Work Family Conflict in Women Who Runs the Family Business
}

\author{
Saiful Anwar ${ }^{1}$, Rusmaini², Lodya Sesriyani ${ }^{3}$ \\ Pamulang University \\ dosen00902@unpam.ac.id ${ }^{1}$,dosen02066@unpam.ac.id²,dosen01852@unpam.ac.id ${ }^{3}$
}

\begin{abstract}
This research is qualitative research that aimed to photograph the occurrence of work family conflict problem in Mistari's family business. The focus of this research addressed to women who control the business located in Blitar district. The main informants in this study were seven women who control family business in various fields ranging from restaurant, beauty salon, farm, sewing to suppliers of second hand. The data collection procedures used to construct this research included interviews, observation and documentation. Based on the results of the qualitative data analysis, the description of the work family conflict condition that occurred in the Mistari's family business is as follows: 1) work family conflict occurred in all women who ran the business especially for some women who had become head of the family because they no longer have couple. Therefore, the sub business was run with children, daughters and grandchildren; 2) the two-dimensional work family conflicts.
\end{abstract}

Keywords: Family Business, The Dual Role Conflict, Women, Work Family Conflict

\section{Introduction}

Indonesia becomes an integral part of the global economic development, as the borders of the state were melted due to the integration of the world economy. The consequence of globalization is that people in Indonesia can access all kinds of information needed including those related to family economic welfare. Unwittingly, the current role of women in the family has shifted considerably over the past few decades. The position of women not only as "konco wingking" (limited friends in the kitchen, wells and mattresses) for men in the family, but also acts as a partner of life in wading the ark of the household including as a friend to discuss in any case even as a partner in running a business.

One of the consequences that must be realized if a wife acts as a partner in running a business is that the role she has to do becomes more numerous, not only as a wife or as a mother but also as a co-worker in a joint business. This will be aligned if a woman can place her role equally in the family and in the work environment. But in reality not all women can easily balance the role because of the both environments, although different places or conditions remain interconnected.

Women with their nature as a human being who has a subtlety in acting and behaving, sometimes tend to think about the impacts of their actions, whether to hurt others or bring a good impact for others. Moreover when it comes to family affairs, usually a woman who has become a mother and wife will be willing to do anything for the sake of her family even though she herself will eventually become the victim of her actions. Based on nature as described above, women especially those who become business partners in their family often experience a role conflict or work family conflict. Work family conflict has many definitions, 
one of which is proposed by Greenhaus \& Beutell (1985) who states that work family conflict is a form of conflict between roles where the pressure on the role of the family and work domains are at certain levels so that involvement in one role makes it difficult for one's participation in another. This role conflict is based on the observation of the researcher the greater the chances of the occurrence if the woman is engaged in a family business where the family business is still managed traditionally. Family business is a booming business happening in Indonesia today. Simanjuntak (2010: 113) states that more than $95 \%$ of businesses run in Indonesia are owned or controlled by the family. Meanwhile, according to dictionary of law (2000), family business is company where most of shares are owned by members of the same family. This is in accordance with the observation of researchers that almost most of the business conducted in Indonesia is a business controlled by the family, especially businesses that belong to the class of SMEs (Small and Medium Micro Enterprises). Often these businesses are managed jointly between husband and wife.

Family business in addition has many advantages but also has some disadvantages. One of the weaknesses is the work of family conflict. Jimenez et al. (2008) argues that work family conflict is a conflict that refers to the extent to which the relationship between work and family is interrupted or in other words the imbalance between work and family so that it brings bad impact to the happiness of family and employees in the family business. Work family conflict has two forms: work interfering family (WIF) and family interfering work (FIW). WIF is a condition where the experiences that occur in a job carried by a woman disrupt the woman's role in married life, WIF usually occurs because of the pressures that exist in the workplace, the number of work demands to be solved, that the time with the family is decreasing due to the activities in workplace which can even decrease the commitment and responsibility to the family.

Meanwhile, family interfering work (FIW) is the pressures of women because their role in the family interferes with the role in the work. FIW itself often occurs due to pressure factors of the marriage itself as well as the pressure of the parents, because in Indonesia a married person will not be directly $100 \%$ of parents off hand. It often happens that the couple still gets the intervention (pressure) of the parents. Greenhauses and Beutell (Sianturi \& Zulkarnain, 2013) mention three dimensions of work family conflict (1) time-based conflict, a conflict that occurs when the time available to fulfill the role in the family (work) cannot be used to fulfill the role in the family (Work) in other words at the same time women will not be able to do two or more roles at once; (2) a strain- based conflict, a tension caused by one role makes a person difficult to meet the demands of other role; and (3) behavior-based conflict, a conflict that arises when the pattern of a behavior in the role that is executed is not in accordance with expectations of behavior on the other role.

\section{Method}

This research aims to show whether there is a work family conflict problem in the Mistari's family business and how the solution is done when experiencing work family conflict. This research includes qualitative research. Borg and Taylor (Moleong, 2007: 3) suggests that qualitative research is a written research procedure that produces descriptive data in the form of written and oral words of the observed persons and behaviors. The qualitative approach in this research was more natural, descriptive, and inductive. Natural means that the background of this study was a natural source of direct data that required the researchers to be 
able to explore directly into the background of research that was nothing but the environment where the researchers lived. Descriptive means that the data collected tends to be words or images. Therefore to provide support to the description presented in the research report researcher disclosed excerpts from the data as a result of the disclosure of respondents. This approach was also selected because this study emphasized more on the disclosure of the meaning of the data or information to be collected in the form of background-based descriptions, problem formulation and research objectives.

The qualitative research conducted in this study addressed to women who control the Mistari's family business located in Blitar regency. This research was done on natural objects and conditions (natural setting). A natural object is an object that develops as it is, not manipulated by the researcher, and the presence of the researcher does not affect the dynamics of the object. In qualitative research the instrument is a person or "human instrument", ie. the researcher himself. The main informants in this study were seven women who controlled the family business in various fields ranging from restaurants, beauty salon, livestock, sewing to second-hand suppliers. The time required in this study was a total of 6 months within 3 years from 2014 to 2016.

The data collection procedures used to construct this research included: interviews, observation and documentation. The Interviews were conducted using unstructured and indepth interviews to obtain the desired data as naturally as possible. The Interviews were conducted using $100 \%$ of Javanese language. The observations made in this study used a type of participant observation but were not seen. The documentation was only used if there were things that needed to be immortalized so that the objectivity of the researcher was maintained. The research data analysis activities used interactive models from Miles and Huberman (1992) and were inseparable from the following four activities: 1) data collection; 2) data reduction; 3) presentation of data; 4) conclusion/verification. To validate the findings of the data in this research, checking techniques were used with the criterion of degree of trust (credibility). The validations conducted among others were: 1 ) extension of observation time;

2) triangulation; 3) member check; 4) audit trail; 5) expertopinion.

Based on the results of the qualitative data analysis, it was obtained a description of the conditions that occurred in the research area of the Mistari's family business, is one family business with the concept of simple SMEs where the family business consists of several businesses that are interconnected between one business with other businesses, which are at least 7 major business run. The main managers were all women who still had good family relationships that had it because of heredity, brotherhood or marital affinity. Although the family business was in the form of SMEs and done a maximum of 50 meters from the residence even most of the business was run united with the house.

\section{Result and Discussion}

Work family conflicts that occurred in the Mistari's family business in detail will be described in the following coherently: first, work family conflict occurred throughout the women who ran the Mistari's family business especially for some women who had become head of the family because they no longer had partner because separated by death or divorce. Therefore, the sub business was run with children, daughters and grandchildren.

Second, work family conflict often occurred during the research period within this family business. Four women tended to experience WIF (work interfering with the family, a conflict 
that arises when the role of work interfere with the role of someone in the family always happens when the woman acts as a mother, while the position as a wife they did not experience significant constraints. This is very human because the researcher realizes that as a mother, time will never be enough, because it has become a nature that a mother always wants to give the best that they can for their children. While this conflict did not happen as a wife because the husbands in this family were open minded and the kind of husband who wanted to share work and household duties with his wife. Moreover, three women often experienced FIW (family interfering with the work), a conflict that arises when the role of a person in the family interfere with the role in the job.

Therefore to overcome this several times the woman closed the business temporarily in a period of three to one week, which was useful to refresh their business brain. In 3 years the researchers found out that the women did long trips 5 times out of town such as go to Bali in 1 week, then go to Bromo for 3 days, then go to Jogja for one week as a solution when there work family conflict occured. The solutions performed by the women, according to the researchers, though simple but had a positive impact on their lives because if there was no solution then as Obradovic (2008) suggests that based on research conducted that the WFC proved to have a negative impact on many variables related to work and family.

Third, viewed from the dimension of work family conflict, it is in line with the idea disclosed by Greenhaus and Beutell from time based conflict, strain cased conflict and behavior based conflict. There were only two occurred: time-based conflict and strain-based conflict. Time-based conflict is a conflict when the time available to fulfill the role of work cannot be used to fulfill the role in the family. In other words, working hours were more than the role in the family. In this research, time-based conflict occurred in women who ran separate business units from family homes so that women felt less maximal in educating children even though they ran a family business. Despite the fact that the business unit was very close to home but when doing the process of observation and interviewing, the problem time based conflict was evident.

In details, time based conflict occurred due to several factors: 1) the environment surrounding the family business can be said to still had a Javanese culture custom so that conscious or not aware of the feeling would appear; 2) the form of business carried out largely in the form of a service business that was packaged in a traditional way so it required a long time and full of concentration; 3) entrepreneurial blood was indeed owned by this family so that although financially fulfilled by the husband's income but the women still ran a family business on the grounds rather than free time wasted and unproductive or feel affection because the business had been pioneered since the women were not married; 4) as a form of self-actualization of a woman in her role in society and family.

Like the hierarchy of needs developed by Abraham Maslow, in which he argues that there seems to be some sort of hierarchy governing the needs of man himself. At first humans need food, clothing, and boards called physical needs (psychological needs). When the activity of this physical need fulfillment began to decline then rise to another need is the need to obtain security. When physical and security needs are met then it shifts to social needs, which are socializing, affiliating with each other, and seeking meaningful relationships. If all the organizations in the community have entered, many friends and no leisure time have reached its social needs. Then will arise the need for an award that is a need for others to appreciate himself and the efforts for what he did. Finally, if the needs of this honor are fulfilled then the most important need is self-actualization.

The second dimension that occurred was a strain-based conflict, a tension caused by one role makes a person difficult to meet the demands of other roles. In this research, strains based 
conflicts occurred several times because sometimes the work affairs carried away when they played the role as a mother then fatigue, anxiety and quick temper could happen. As the above explanation, women in this family had a good entrepreneurial spirit so that totality in work really took precedence. This totality had an impact on family life and often family chats were not far from the business. Because the attitude of totality and perfectionist in the work then if something in the family that was not supposed to be the value of ugly children or dirty pages have not been swept by the assistant of housewifery would make the women emotionally easily ignited. The solution done in case of this problem that women did was to be alone, or the popular term is "me time" by sleeping, going to the salon or usually spending on their own.

Meanwhile, the third dimension of behavior-based conflict did not occur because during the observation of researchers the behavior they did at work and home were the same or have no difference between attitude at home and workplace for many years.

\section{Conclusion}

In this research, there were only two work family conflicts which occurred; time-based conflict and strain-based conflict. Time-based conflict, a conflict when the time available to fulfil the role in the job cannot be used to fulfil the role in the family or in other words work hours at work were more than the role in the family. In this research, time-based conflict occurred in women who ran separate business units from family homes so that women felt less maximal in educating children even though they ran a family business. The second dimension that occurred is a strain-based conflict; a tension caused by one role makes a person difficult to meet the demands of other roles. In this study strain based conflict several times occurred when sometimes the work affairs carried away when they act as a mother and that fatigue, anxiety and quick temper happened. Meanwhile behaviour-based conflict did not occur because during the observation of many years their behaviour at work and at home was the same or no difference between the attitude at home and at work.

\section{References}

[1] Arikunto, Suharsimi.: Manajemen Penelitian. Rineka Cipta, Jakarta (2005)

[2] Bogdan, R. C \& Biklen, S. K.: Quantitative Research for Education: An Introduction to Theory and Methods. Allyn \& Bacon, Boston (1992)

[3] Budiana, Gomulia.: Bisnis Keluarga di Bandung. Bagaimana Mereka Berlanjut?. Vol 12 No 2 Desember (2013)

[4] Creswell, J.W.: Qualitatif Inquiry and Research Design. Sage Publication, Inc, California (1998)

[5] Cyntia A Thompson.: When Work Family Benefits are not enough: The Influence of WorkFamily Culture a Benefit Utilization, Organizational, Attachment and Work Family Conflict, pp. 392-415. Journal of Vocational Behavior 54 (1998)

[6] Denus, Farida.: DR BRA Moeryati Soedibyo: Penerus Perusahaan Kadang Tidak Berlangsung Lama. Suara Pembaharuan. Sunday, September 9th 2007, pp. 2 col. 1-6 (2007)

[7] Grandey \& Bryanne \& Ann.: A longitudinal And MultiSource Test of the Work Family Conflict and Job Satisfaction Relationship. pp. 305-323 Journal of Occupational and Organizational Psycology 78 (2005)

[8] Greenhouse \& Beutell.: Sources of Conflict Between Work And Family Roles. Academy of Management Review. 10(1), pp. 76-88 (1985) 
[9] Hurlock, Elizabeth B.: Psikologi Perkembangan. Erlangga, Jakarta (1996)

[10] Laksmi \& Hadi.: Hubungan Antara Konflik Peran Ganda dengan Kepuasan kerja Pada Karyawan Bagian Produksi PT. X. Vol 1 No. 2. Jurnal Psikologi dan Organisasi (2012)

[11] Michael R frone.: Developing and Testing an Integratif Model of The Work Family Interface. pp. 145-167. Journal of Vocational Behavior 50 (1997)

[12] Moleong, L. J.: Metodologi Penelitian Kualitatif. Rosda Karya, Bandung (2007)

[13] Moslow, A.: Motivation of Personality. Harper and Brother, New York (1954)

[14] Roboth Y Jane.: Analisis Work Family Conflict, Stress Kerja dan Kinerja Wanita Berperan Ganda Pada Yayasan Compassion East Indonesia. Vol 3 No 1, pp. 33-46. Jurnal Riset Bisnis dan Manajemen (2015)

[15] Sianturi \& Zulkarnain.: Analisis Work Family Conflict Terhadap Kesejahteraan Psikologi Pekerja. Vol 1 (3), pp. 2017-215, Jurnal Sains dan Praktisi Psikologi (2013)

[16] Simanjuntak, Augustinus.: Prinsip-Prinsip Manajemen Bisnis Keluarga Dikaitkan dengan Kedudukan Mandiri PT. Vol 12 No 2 September 2010, pp. 113-120, Jurnal Manajemen dan Kewirausahaan (2010)

[17] Sugiyono.: Metode Penelitian Pendidikan: Pendekatan Kuantitatif, Kualitatif, dan R\&D. Alfabeta, Bandung (2010) 